\title{
GROWTH PERFORMANCE AND SERUM BIOCHEMICAL PARAMETERS OF BROILER CHICKENS FED DIETS CONTANNING NIGELLA SEED MEAL
}

\author{
M. H. Soltman and G. R. El-Sayed* \\ Dept. of Nutritlon \& Clinical Nutrition, Fac, of Vet. Med.. Zagazlg Universlty \\ 'Dept. of Biachemistry and Chemistry of Nutrition Fac. Of Vet. Med., Mansoura Universtly
}

\begin{abstract}
A 6-uk feeding tral with 240 day-old Hubbard broiler chicks was conducterd to studly the clfect of feeding diets contaliting Nigclla seed meal on growih performance. some senum blochemical parameters and activilies of some liver enzymes. Durning cach feeding phase (starter, grower and funisher) isonilrogenous and isocalortc dicts uvere formulated. where Nigella scert incal uns included at three levels to supply amount of protein equal to 25.50 or $75 \%$ of the protein amount supplied by soybean meal in the mntrol diet. The resulls showed that the use of Nigella seed meal to supply amoumt of protein equal to $25 \%$ of the protein amount supplled by soybean meal in the control dict has significantly ( $P<0.01)$ increased final body weight, body gain. feerl conuersion ratto and feed effctency, while no signlficant differences were detected when Nigella seed ineal was used to supply 50 or $75 \%$ of the prolein anount supplierl by solyixem neal in the control dies. However, inclusion of Nigella seed nueal in the brouler diets did not signiflcanily ( $P>0.01$ ) affect the tolal feed consumptlon, although broller chichens tenderl to consume more ferd as the amount of protein supplied by Nigella seed ineal in the dict increased. Feed costs urene relatively low when Nigella seed meal toas isser to supply amount of protein that would replace 25. 50 or $75 \%$ of the protein. Compared to the control, senum concentrations of 73 and T4 uere significantly $(P<0.01)$ increased wich Nigella seed meal was used to supply annount of protein that replaced 25.50 or 75 sh of the proteln amount supplled by soybean meal in the control diet, while glucose concentrattons were signiflcontly decreased. Scrum concentrations of globulin were sigItificanlly ( $P<0.01)$ elevated at all used levels of Nigella secd meal. while senm tolal protein concentrotion was siynificantly increased only when Nigella seed incal ukes uscel to supply $25 \%$ of the protein. Triacylglycerol and total cholesierd concentrations tucre significantly reduced when Nigella seed mexal was inchided in the die's to firmish
\end{abstract}


anount of protetn substluting 25. 50 or $75 \%$ of the protent amount provided by soybeall me..l In the control diet, while high deprsity lipoproteins were significantly increased only when 75 of of the protetn amount supplied by soybean meal in the control dict was replaced by equal amount of proteut provided by Nigella seed meat. Vilumin $C$ and glycogen concentrations uvere significantly $(P<0.0 I)$ increased in hepatic tissues of chickens fed diets contained Nigella seed meal regardiess of the ainount used. The artinily of lliver enzymes (AST. AIT and GGT) were not significantly (P > 0.01) affected when either 25 or 50 of soybcan meal protein in the control diet was replaced by equal amount of Nigella seed mural protein, while the activity of these crzymes uas significantly affected when 75 of of Nigella seed meal protein was used. Under the conditions of this study. it could be concluded that Nigella seed meal could be successfinlly used in brailer diets to supply amount of protein that could replace $25 \%$ the protein amount supplied by soybean meal with favorable effects on growth performanow. feed effictency and biochemical parameters.

\section{INTRODUCTION}

As Feed expenses constllute $651070 \%$ of the tolal poultry production costs and most. il not all. of tic traditional protein supplemenls used in formulating poultry diets have to he imported. therefore any trials to search alternative proteln supplement and to reduce feed costs arc of Interest. Soybean meal is one of the most whdely used protein supplement, 1 has the highest enercy and the lowest Bber content aniong all oil seed meals and provides the most cconomical quallty protein avallable to the focd manufneturer. Ilowever, the drastle increase in price and the short supply of soybcan ineal. espectally In recent years. are ones of the main obstueles faelng poultry Industry in Egypt. Therefore, nutruontsts are always forced to search for other alternaIIve cheap proleln supplements.

In Egypt. there is a growing Interest to cultuate Nigella seed as a medicinal plant. The seeds are tradllionally uscd as carninative and llavoring and also exhlbit anlbacterlal, antllungal, antidfabetic and bronchodllator eflects (Soliman et al., 1999; Agel. 1993 and Sharobeem, 1996). The most Important nutrent of Nigclla seed is its oll content (37\%), whieh is primarlly used for medicinal purposes (Abdel-Aal and Attla, 1993). When the oll Is removed the residue reinalning behind is called Nigella seed meal (NSM). However. IImited Inlomatlon arc avallable concenilng the use of NSM although it has a potentlal nutritional charactertstics, the most important of which is its high prolcln conteni. $30 \%$ or more and the relatlvely high encrgy supply. 2800 Kcal/kg ME (Khallfah, 1995 and Zewell, 1996). NSM̈ proteln has been successfully and eco- 


\section{T. I. Mohamed \& G. R. El-Sayed}

nomlcally used as a partial substitution for sunflower meal proteln (Awadalla, 1997) and for soybean mcal protcin (El-Ayek, 1999) in diets tor growing lainbs. The amino acid composition of NSM was detcrmined for the flrst tIme by Babayan et al. (1978). They lound that its proteln Is rich In arglnine, glutamic acid. leuclne. phenylalanine and lysine. Nigclla seeds are also a good source of some physlologlcally Important elcments such as $0.28 \% \mathrm{Na}, 0.25 \% \mathrm{Mg} .0 .79 \% \mathrm{~K} .34 \mathrm{I} .9$ ppm Fe. $56.3 \mathrm{ppm} \mathrm{Zn}$ and $8.7 \mathrm{ppm} \mathrm{Cu}$ (Soliman et al., 1999). There is a revived Interest among producer to use NSM as Irnniunostinulant in poultry diets. However. IImited researehes have been conducted to study the NSM as a source of prolein in poultry diets. Khallfab (1995) stated that NSM contained most of the essentlal anino acids and eould ofler a fairly elseap source of proteln for poultry. Moreover, the oll left in NSM is rich in oleic and linoleic actds, which are essential for poultry (Ustun et al., 1990). Zewell (1906) found that Inelusion of NSM at 6.78 and $13.54 \%$ in growing Japanese quall diels has improved performance parameters. On the other hand the use of Nigella seeds at $0.15 \%$ and $0.30 \%$ in broller dlets has improved the Imnmunity without ally signifleant eflect on perfombance parameters (Sollman et al., 1999). However. the levels used In the previous studles may be not high enough to eliclt a elear effeet on broller perfornance. 'Therefore, the present work was designed to study the growth perlommanec, serum blochemleal parameters and actlvity of some liver enzymes of broller ehleken when NSM was used to supply atnount of protein that would replaee 25,50 or $75 \%$ of the protein amount supplied by soybear: meal in the diet.

\section{MATERIALS AND METHODS}

\section{Experimental dlets :}

Nigella scod cake was obtalned from a local processing unit at Mansoura City. Dakahlia govcmoralc. 'The cake was ground into meal to pass through 1 -rnm mesh screen for casy mbung with other ingredients. Samples of NSM and the used feedstults were analyzed for CP. EE and CF percentages aeeording to AOAC (1900). The chemical composition of the feedstults used in formulatlon of the diets is shown in Table I. NSM was included at difTerent levels in the diets 111,22 and 33\% In starter dicts: 9.17. 18.33 and $27.50 \%$ in grower diets and 6.8, 13.35 and $20 \%$ in linisher dtets) to supply anount of proteln that would replaee 25.50 or $75 \%$ of the proteln ansount supplied by soybean meal in the control diels. Four dlets lone control and three experimental\} were formulated at each fecding phase, aecordingly a total of 12 diets werc used (Table 2). The diets fed at each phase were formulated to be almost Isocalortc. Isonitrogenous. nearly equal in respect to other nutrlents, as specifled in the user's gulde of Hubbard. The diets were supplemented with L-lysine hydrochlorlde. DL-methionlne. sudium blearbonate and chollne 
chloride to balance for these nutrlents as recommended by NRC (1994).

\section{Experimental chicks :}

Two hundred forty nulxed scx, day-old Hubbard broiler chlcks, obtalned from a local commerclal hatehery, were randomly distributed to four groups. Each group was rcplleated three limes eaeh of 20 chicks. Chleks were housed in well-disinleeted houses with wheal straw as in bedding materlal. The groups were randonly assigned to the experimental dlets. Feed and fresh clean water was provided for ad llblium consumpllon. The experiment was carted out on July through Augusl. where ehicks were fed the diets ior 6 weeks.

\section{Growth performance and blochemieal parameters :}

Throughoul the expcrimental period. average feed consumption and body weight galns wcre reeorded at weekly Inlervals, from which body galn and feed conversion were ealculated. For ease of comparison. data were presented blweckly. At end ol the experinent. 12 chickens per group were slaughtcred for collection of bloud and tissue samples. Blood samples were centrijuged and only clear sera were collccicd and used for analysls of (rllodothyronine (13) (Cooper, 1982), thyroxlne (T4) (Schall et al., 1978). lotal protelns (Cornel et al., 1949). albumin (Doumas, 1971), globul!n was calculated by subtracting albumin from total proteins. glucose (Trinder, 1969). Irlacylglycerols [Young and Pustaner, 1975), lotal choles(erol (Melattin\}, 1978). high deısilty lipoproteins (Clark et al., 1983), low denslty lipoproteins (Frtedwald et =1.. 1973), uspartatc amthotransferase (AST), alanine aminotransferase (ALT) (Reitmann and Frankel, 1957) and gamma glutamyl transicrase [GGD (Persljn and Vonderk. 1976). L.Jver IIssue samples were 11 s'(l) for analysis of vilamin C (Roe et al., 1948) and glycogen (Carrol et al., 1956).

\section{Statlotical analygis :}

Data were subjeeted to analysis of vatiance by general linear models (CLM) proecclures of SAS (SAS. 1996). Slgnilieant differences among main cllecl means were separaled by Dunean's mn1. tlple range tesI with 1 \% level of prohabllity.

\section{RESULTS AND DISCUSSION}

\section{Growth performance :}

The maln elfeet of NSM on bexly welght, body galn. leed intake and feed conversion ratto durIng the starter perlod is presented in Table 3. Data revealed that the use of NSM at $11 \%$ to provlde amount of proteln replaeing $25 \%$ of the protein amount supplled by SBM in the control diet has sIgnllieanlly (P < 0.01 ) increased body welght, body galn when eompared to the olher dletary treatinents. No signifleant differences were detected when $50 \%$ of the proteln amourit supplied 


\section{T. I. Mohamed \& G. R. El-Sayed}

by SBM In the control cliet was replaced by equal amount of protefn derived from NSM (22 \% NSM in (lice dicl). On the other hand. incluston of NSM at 33\% to provide amount of protein substlluling $75 \%$ of the protcin amount provided by SBM In the control diet has signifleantly ( $\mathrm{P}<0.01)$ rcluced body welghl and body welght galn when compared to the other dielary treatments. lieed intake was significantly $(\mathrm{P}<0.01)$ deereased when $75 \%$ of the protein amount provided by SBM in the control diet was substiluted wth equal amount of protein derlved from NSM. Use of NSM at $11 \%$ and $22 \%$ of the dict has signilicanlly $(P<0.01)$ Improved feed conversion ratio (1.31 and 1.39, respectively) when compared to the control, while 33\% of NSM in starter diet has no significant $(P>0.01)$ elfect on leed conversion ratio (1.46) compared to the control diet [1.42].

The growth performance data of broiler chicken led the grower and Anisher diets are shown in 'Tables 4 alucl 5, respectively. it is clear that the best growlh performance parametcrs were obtained whrn $25 \%$ of the proteln anount supplied by SBM in the control diel was substltuted with equal amount of protein provided by NSM 19.17 and 6.80\% NSM In the grower and linisher diets. respectlvely) followed in the order by $50 \%$ substitution of the proteln amount (18.33 and $13.35 \%$ NSM in the grower and linisher dicts, respcctucly). whlle $75 \%$ substitution of the protein amount supplied by SBM in the control dict wlus equal amount of proteln obtalncd from NSM (27.5 and $20 \%$ NSM in the grower and finisher dicts. respectuvely) has resulted in the lowest perlormance parimeters. It Is worthy to note that recd intake, during the growing and finishing periods. tended to increase as the level al NSM In the dict increased, while body weight and budy gain tended to gradually decrease. The data also revealcd that feed conversion ratio has been improved whicn 25\% of the protein atnount supplied by SDM in the control dicl was sulustitulcd with equal amount of protein derived form NSM when compared to the other dietary trealinents.

The allover growth performance data (Table 6) showed that Inclusion of NSM at 11.9.17 and $6.80 \%$ of the dlet to provide arrount of protedn replacing $25 \%$ of the protcin amount provided by SBM in the starter. grower and finisher diets, respectuvely has signiflcantly $(r<0.01)$ Inereased the final body wcight ( $1650 \mathrm{~g}$ ), tbe final body galn ( $1605 . \mathrm{Bg}$ ) and improved the feed conversion ratlo (1.98) when compared to the control diet (1525 g. 1480.8 g and 2.15, respectively). No signilieant dillerences In final body weight. linal body gain werc detected when either 50 or $75 \%$ of the proletn anount supplicd by SBM in the control dlet was replaced with equal anount of proIcin derlved fiom NSM. However. replacing $75 \%$ of the proteln amount provided hy SBM In the control dict ivith equal amount of prnteln from NSM throughout the whole fecding period has produced the luwest performance. Inclusion or NSM In brolker chicken diets has no slgnifleant effect on total feed intake. although it tended to increase as the percent of NSM in the diet increased. Broiler chlekens fed diets in whlch NSM was uscd al 11,9.17 and $6.80 \%$ to provide 


\section{H. Solis, $\Omega$ and G. R. El-Sayed}

aniount of protedn replacing $25 \%$ or the proteln provided by SBM in the control diets had utllized thelr fieed nore efliclently (50.29\%) compared to those fed the control dlcts $146.58 \%$ ). while other groups werc not different fron the control.

The signiflcant higher growth perforinance parameters obtained when NSM proteln replaced $25 \%$ of the protein amount provided by SBM in the conirol diets could be due to Improved metabollc activity Induccd by the increased serum concentratlon of thyroxin (Table 7). Thyroxin horinone was lound to increase hepatic synthesls of RNA (Taha and Windel. 1966) and ineorporaIIon of amino aeids Into protein and hence protein synthesis (Baccari et al., 1983). SInilarly. substlution of $25 \%$ of clther wheat prolehn or faba mcal protein with Nigella protein in diets of rat has 1ncreascd growth rate and boxly weight (Sharobeem, 1996 and Al-Gaby, 1998). Khodary et al. (1996) found that inrlusion of Nigella seed at either 1 or $2 \%$ has increased the concentration of thyroxin hormone in blood of laying hens with consequent increase in egg production. Ilowever. the role of Nigella sect compounds as antinicroblal in treating subelinical infections and improvlng health stalus of clifckens cucild not be neglected (Rathee et al., 1982 and Alcrander. 1985). The volatilc ofl in Nigclla seed mcal was found to exert antimicroball and antlfungal propertles due to presence of rertaln active compounds such as nigcllone and thymohydroquinone (Farlda and Khalld, 1987). There might be some snrt of complementary relationslup between SDM and NSM protelns. On the ol her hand. the decreased performanec of broiler chlcks when NSM protein had replaced $75 \%$ of the amount of proteln supplled by SBM in the control diet. although feed Intake was nol decreased. could be due to low supply ol some essential amino acids such as arginine and leucine or amino acid imbalance. The dietaly balance of amino ackds niarkedly inllucnces the efliclency with which amino acids are used for growth and other physlologleal proccsses. Austic (1994) stated that excess or lack of some amino acids depresses the growth by mcchanisms that appear largely independent of lood Intakc. Arginine conlent of NSM was found to be low (0.69\%) as compared to 3.14\% for SBM (Zewell, 1896). The use of NSM protein to replace $75 \%$ of the proteln amount provided by SBM in the control diet could have induced argininc deflelency relatlve to lysine. Arginine was found to stImulate giowth hormone rclease fiom pltultary gland. Moreover, arginine is one of the three amino aclds makeup ereatinc. which is well known to inereasc the energy ATP cyele (Balsom et al., 1994 and Wlllams ct al.. 1999). Radwan (2001) found that growth performance of local cockercl has been reduced when Nigella sced meal replaced $60 \%$ of soybean meal in starter-growcr dict. Also apparcnt availabllity of arginine and lysine in Nigella seed mcal were found to be lowcr than that in soybcan meal (Khallifah, 1995). A good balance of lysine and arginine docs result in release of hiologically active hormone able to affcct pertpheral cellular receptors and Uus cell growth in general (Casey and Greenbafr, 2000). It is worthy to note that the final body wcights obtained 


\section{T. I. Mohamed \& G. R. El-Sayed}

under conditien of this experiment are evidently lower than the target body weights expeeted for the Hubbard breed. This was a consequenee of the high covironmental temperature (more than $37^{\circ} \mathrm{C}$ ) and the relative humidity prevailing at ume of the experinient.

\section{Serum blochemical parameters :}

Scrum biod imical paramelers of broller chickens licd diets containing NSM are shown in Table 7. Sermm coneentrations of thyroid hormones $\left(T_{3}\right.$ and $\left.T_{4}\right)$ were slgnificantly $(P<0.01)$ increased when NSM supplled amount of proteln equal to 25.50 or $75 \%$ of the proteln amount supplied by SBM in the control diet. This increase nay be due to the stimulatory eflecl of Nigclia seed on thyrold gland either directly or through the pltultary level (Lee and Knowles, 1965; and Khodary et al., 1996). Our results revealed a signiflcant reduclion in serum glucose level when NSM protein replaced SBM proteln as compared to the control group. However, the reduction was more intense when 75\% of the amount protelı supplled by SBM In the control dict was substlluled will equal amount of protein clerived form NSM. The reduction of serum glucose could be due to the reduction of gluconeogenesis by actlve compounds In NSM througl lowering of glucogenle encymes (Al-Awadl et al.. 1991). In addilion the signiflcant Increase in thyroid lormones riported in thls study could be the maln cause ol the decline in glucose concentration through increasing the sensitivity of Ussucs to insulin (Robert et al., 1996). This concept Is supported by the Andings of Shetty et al. [1996) and Torrance et al. (1997) where T3 was lound iv s(1mulate insulin responslve glucose transporter and transcription (GLUT1 and GLUT4) in ral.

Replacing $25 \%$ of the protein amount supplicd by SBM in the control dict wilh equal amount of prolcln derived from NSM has signiflcantly ( $\mathrm{P}<0.01$ ) increased total protein concen(Jation 111 serum of isroller ehlcken when compared to the control ones, while no signiflcant difierences wcre detecled when elther 50 or $75 \%$ of the proteln anount supplied by SBM in the control dict was replaced with equal arnounts of NSM protcin. On the other hand, serum albumin concentraIton was signillicantly decrcased at all the replacement levels when compared to the control diet. with the lowest concentration recoided at $50 \%$ rcplacement level. Serum globulin concentration was signifitantly ( $P<0.01)$ increased when NSM prolein has replaced SBM protein at all used levcls compared to the contml, whth the lighest concentration recorded at $25 \%$ level of replaeeinent. The signincant inercase 1 in serum globulin concentration of broller chicken led NSMrontalning dlets could have resulted from the inimunostinnulant effect of NSM protein (Aqel, 1993). Thesc results are in accordance with AJ-Gaby (1998) who fourid that substitution of 25 $\%$ of com or litisa meal proteln with Nigella cake protein has significantly lncreased serum total proteins and globulin concentratlons in rats. In addition, higher thyroxtn level, as recorded in 


\section{H. Soliman and G. R. El-Sayed}

our study, was found to stlmulate prolein biusynthesls (Habeeb et al., 1989).

Data in Table 7 showed that NSM prolein has a significant effect on serum ilpld profle of broiler chickens. Serum triacylglycerol ('TAG) and toial cholesterol concentrations were signifcanty $(\mathrm{P}<0.01)$ decreased when 25.50 or $75 \%$ of the protein amount supplied by SBM In the control dict were replaced with equal amounts of NSM proteln. On the other hand, there was a signifleanl increase in high density lipoproteins (HDL) and a significant decrease in low density lipoprotein (LDL) when elther 25 or $50 \%$ of the protcin amount supplled by SBM in the control diet was substituted with equal amount of NSM protein, while 75\% substitution level has signincantly (P<0.01) increased serum conecntration of both HDL and LDL when conpared to the control. An fncreased serum $\mathrm{T} 4$ found in this study could be the plausible explanation for the significant decrease in trlacylglycerol and tutal cholesterol. This explanation Is supported by the work of Habeeb et .... (1989), where thyroxin injection of rabblts reduced scrum lotal IIplds, cholesterol and glıcosc. Anf and Daghash (1999) and EL-Dakhakhny et al. (2000) obtalned relatively coinparative results when Inclusion of Nigclia seeds at $2.5 \%$ in gestation and lactatlon diets of rabilits las induced hypocholesterolemic ellect. The unsaturated fatty aclds In Nigella secds stimulate cholesterol excretion inlo the Intestinal tract and its oxldation to hile acids. Also. Zaoul et al. (2002) found that oral dosing of Nigelia sced fixed ofl at rate of $1 \mathrm{ml} / \mathrm{kg}$ body wclght has decreased serun cholesterol and triacylglycerol in rat. Our results support the traditlonal use of Nigella seed as a treatment of dyslipldenia, hyperglycemla and relaled abnormalities.

Vitamin $\mathrm{C}$ and glycogen concenlratlons $\mathrm{in}$ hepatic lissues as wcll as actlvity of serum Iransaminases in hroiler chicken fed the experimental diets are shown In Table 8. Vitainin $\mathrm{C}$ and glycogen concentrations were slgnilicanlly (P<0.01) higher in hepatic tissues of broiler chickens when 25. 50 or $75 \%$ of the protein amount provided by SBM in the control dict were replaced with cqual amounts of NSM proteln. This may be attributed to the stimulaulon of $\mathrm{T}_{3}$ and $\mathrm{T}_{\mathbf{4}}$ secretion. whicls enhance the cflect of insulin (Shetty et al., 1996). It appears that thyrold hormones regulate glycogen content between liver and muscles. In support of this statcment. Nabukuni et al. (1989) lound a decrease in musele glycogen of thyroldeclomized chlcks, and when these ehicks were given ' $\mathrm{T}_{4}$ Injeclions an apparent increase in muscle glycogen was reconded. SInilarly. Caraline (1991) reported an increase in myocardlal glycogen in hyperthyroid pouits. The effect of NSM prolcin on the actlvity of serum Iransanilnases was minor. Substituting 25 or $50 \%$ of the protein aniount supplied by SBM in the control with equal amounts of NSM protein has no significant ( $P>0.01$ ) effect on the serum levels of aspartate amtnotransferase (AS'I), alanine aminotransferase (ASLT) or gama glutanyl transfcrasc (GGI). compared to the control, while scrum levels of these enzymes wcre signifleantly ( $P<0.01$ ) increased when $75 \%$ of SBM proleln in the control ditt was replaced with equal amount of proteln supplied by NSM. Our resulls are sup- 
porled by that of Al-Gaby (1998) who found that substitution of $25 \%$ of both corn or faba protefn wilh Nigella proicin in the dlet of rat has no slgnifieant effect on the actlvity of serum iransaminases (AST or ALT), In accordalice with thls respect. El-Dakhakhny et al. (2000) found that oral Intake of Nigclla sced for 4 wccks did not aclversely affect the serum AST or ALT. On the opposite side. Tennekoon et al. (1991) found that oral administralion of aqueous exirael of Nigella seeds to rat has resulted in elevalion In serum concentration of GGT and ALT. Morcover, AST and AI $T$ were elevalcd in serum of rabblts fed Nigella seed seeds (Ann and Daghash., 1999).

Gencrally. from the aforementioned results it could be conclincled that Nigella seed meal could be fivvor; ly Included in broller cllets to provide anount of protcin that would replaee $25 \%$ of the prolcin suppled by soybean meal. This conclusion is based on the Improved growth perfornance parameter and serum metabolites.

'Table 1. Chemical composition of feedsturts used in formulation of the cxperimental dicts'

\begin{tabular}{|c|c|c|c|c|c|c|c|c|}
\hline \multirow[t]{3}{*}{ Feedsluff } & \multicolumn{8}{|c|}{ Chemical composition ( $\%$ air dry basis) } \\
\hline & ME & $\mathrm{CP}$ & EE & $\mathrm{CF}$ & La & $P$ & Lysine & Methionine \\
\hline & $\mathrm{Kcal} / \mathrm{kg}$ & $\%$ & $\%$ & $\%$ & in & $\%$ & $\%$ & $\%$ \\
\hline Yellow com, gromnd & 3335 & $8.5^{\mathrm{a}}$ & $3.6^{\mathrm{a}}$ & $2.3^{n}$ & 0.05 & 0,28 & 0.30 & 0.18 \\
\hline Cont gluten meal & 3720 & $60^{\mathrm{g}}$ & $1.2^{\mathrm{i}}$ & $1.8^{\mathrm{a}}$ & 0.07 & 0.45 & 1.03 & 1.78 \\
\hline Fish ineal & 3185 & $71.5^{\mathrm{a}}$ & $9.0^{A}$ & $0.6^{\mathrm{n}}$ & 3.5 & 2.01 & 5.62 & 2.08 \\
\hline Soybcan neal & 2220 & $44^{a}$ & $1.5^{\mathrm{a}}$ & $6.4^{i}$ & 0.35 & 0.64 & 2.8 .5 & 0.59 \\
\hline Nigella seed meal & $2800^{h}$ & $30^{\mathrm{a}}$ & $10^{\mathrm{a}}$ & $11.5^{\mathrm{a}}$ & $0.25^{b}$ & $0.82^{\mathrm{h}}$ & $1.46^{\mathrm{b}}$ & $1.67^{\mathrm{b}}$ \\
\hline Sunflower oil & 8650 & - & 94 & & $\therefore$ & - & - & - \\
\hline
\end{tabular}

' Values are derived from feed composition tables, NRC (101)4) muless cullucrwisc indicated

a Chemically analyzed according to AOAC (1990).

t According lo Zeweil (1996) 


\section{T. I. Mohamed \& G. R. El-Sayed}

Table 3. Growth performance of broiler ehickens fed the experimenial diets (0-2 weeks)

\begin{tabular}{|c|c|c|c|c|c|}
\hline & \multicolumn{4}{|c|}{ Experimental diets } & \multirow{3}{*}{$\pm \mathbf{S E}^{\mathrm{d}}$} \\
\hline & \multirow[b]{2}{*}{ Control } & \multicolumn{3}{|c|}{ \% Soybeяn meal protcin replacement } & \\
\hline & & $25 \%$ & $50 \%$ & $75 \%$ & \\
\hline Inilial weight, g & 44.2 & $44.2^{\circ}$ & 43.2 & 43.0 & 0.39 \\
\hline Weight at $2-w k, g$ & $361^{h}$ & 394 & $355^{\triangleright}$ & $331^{\mathrm{c}}$ & 8.85 \\
\hline Weight gain, g & $316.8^{\mathrm{b}}$ & $349.8^{2}$ & $311.8^{b}$ & $288^{c}$ & 5.50 \\
\hline Feed intake, $\mathrm{g}$ & $464^{a}$ & $460^{\mathrm{a}}$ & $434^{a b}$ & $408^{b}$ & 10.90 \\
\hline Feed conversion ratio & $1.46^{\circ}$ & $1.31^{\mathrm{c}}$ & $1.39^{\mathrm{h}}$ & $1.42^{\mathrm{ab}}$ & 0.069 \\
\hline Feed eost, LE & 0.41 & 0.395 & 0.366 & 0.34 & \\
\hline
\end{tabular}

¿x Means in the same row will difTerent superscripls are significantly difTerenl $(P<0.01)$.

Standard error of Irealment means.

Table 4. Growth perforninnce of broiler chickens fed the experimental dliets (2-4 weeks)

\begin{tabular}{|c|c|c|c|c|c|}
\hline & \multicolumn{4}{|c|}{ Experimental dlels } & \multirow[b]{2}{*}{$\pm \mathbf{S E}^{\mathbf{d}}$} \\
\hline & & \multicolumn{3}{|c|}{$\%$ Soybean meal protein replacement } & \\
\hline & Conirol & $25 \%$ & $50 \%$ & $75 \%$ & \\
\hline Initial weight, $\mathrm{B}$ & 361 & 394 & 355 & 331 & 8.85 \\
\hline Weight al 4-wk, g & $994^{b c}$ & $1050^{\circ}$ & $1000^{\mathrm{ah}}$ & $946^{c}$ & 16.68 \\
\hline Weight gain, g & $633^{h}$ & $656^{\circ}$ & $645^{\text {th }}$ & $615^{c}$ & 3.24 \\
\hline Feed intake, $g$ & $1240^{\mathrm{Ah}}$ & $1213^{b}$ & $1242^{\text {ah }}$ & $1275^{\mathrm{B}}$ & 15.7 \\
\hline fieed conversion ratio & $1.96^{\mathrm{ah}}$ & $1.85^{b}$ & $1.92^{\text {th }}$ & $2.07^{\mathrm{a}}$ & 0.11 \\
\hline Feed eosh LE & 1.07 & 1.01 & 1.0 & 1.02 & \\
\hline
\end{tabular}

tx Mems, il the same row wilh different supcracripls are significantly difTerent $(P<0.01)$

d Slaudarel error of treatincnt means

Table 5. Growth performanee of broiler clijekens fed the experimental die1s (4-6 weeks)

\begin{tabular}{|c|c|c|c|c|c|}
\hline & \multicolumn{4}{|c|}{ Experimental diets } & \multirow{3}{*}{$\pm \mathbf{S E} \mathbf{E}^{\mathrm{d}}$} \\
\hline & \multirow[b]{2}{*}{ Control } & \multicolumn{3}{|c|}{$\%$ Soybean meal protein replacement } & \\
\hline & & $25 \%$ & $50 \%$ & $75 \%$ & \\
\hline Initial weight, g & 994 & 1050 & 1000 & 946 & 16.68 \\
\hline Final weight at $6-w k, g$ & $1525^{\mathrm{bc}}$ & $1650^{\mathrm{a}}$ & $1590^{\text {th }}$ & $1492^{\mathrm{C}}$ & 22.61 \\
\hline Weight gain, g & $531^{\mathrm{h}}$ & $600^{\circ}$ & $590^{\circ}$ & $546^{b}$ & 3.10 \\
\hline Feed intake, $\mathrm{g}$ & $1475^{b}$ & $1520^{\text {th }}$ & $1535^{\circ}$ & $1550^{\circ}$ & 20.48 \\
\hline liced conversion ratio & $2.77^{\mathrm{ab}}$ & $2.53^{c}$ & $2.60^{\text {be }}$ & $2.84^{n}$ & 0.18 \\
\hline Feed cost, LE & 1.23 & 1.25 & 1.24 & 1.25 & \\
\hline
\end{tabular}


M. H. Soliman and G. R. El-Sayed

Table 6. Allovcr Pcrformance of broiler chickens fed the experiınental dicts (0-6 weeks)

\begin{tabular}{|c|c|c|c|c|c|}
\hline & \multicolumn{4}{|c|}{ Experimental diets } & \multirow[b]{2}{*}{$\pm \mathbf{S} \boldsymbol{E}^{d}$} \\
\hline & & \multicolumn{3}{|c|}{ \% Soybean meel prufcin replacement } & \\
\hline & Conlrul & $25 \%$ & $50 \%$ & $75 \%$ & \\
\hline luitial weight, g & 44.20 & 44.20 & 43.20 & 4.3 .00 & 0.39 \\
\hline Final weight, $g$ & $1525^{\text {he }}$ & $1050^{n}$ & $1590^{\text {uh }}$ & $1492^{c}$ & 20.48 \\
\hline Weight gain, g & $1480.8^{\mathrm{hc}}$ & $16,05^{n}$ & $1546^{\mathrm{Ah}}$ & $1449^{c}$ & 21.79 \\
\hline Tolal [ced intakc, g & 3179 & 3193 & 3206 & 3233 & 33.42 \\
\hline Feed conversion ratio & $2.15^{\mathrm{gb}}$ & $1.98^{2}$ & $2.07^{\mathrm{hc}}$ & $2.23^{\mathrm{a}}$ & 2.23 \\
\hline Fced ctTiciency & $46.58^{\text {ic }}$ & $50.29^{4}$ & $48.15^{\text {sh }}$ & $46.36^{\mathrm{c}}$ & 0.042 \\
\hline Feed cost, LE & 2.71 & 2.65 & 2.61 & 2.61 & \\
\hline
\end{tabular}

abe Means in the salle row with dillerent superseripts ure signilicalnly diflerela (P<0.01).

Standard crror of trealinent ineolss.

Table 7. Bincluemical paramelcrs of broilcr clickens [cut the experiniental dicts for G weeks

\begin{tabular}{|c|c|c|c|c|c|}
\hline \multirow{3}{*}{ Diochemieal paraneter } & \multicolumn{4}{|c|}{ Experimental diets } & \multirow[b]{2}{*}{ $\pm S E^{e}$} \\
\hline & & \multicolumn{3}{|c|}{$\%$ Snybeall nscal protcin replacement } & \\
\hline & Controi & $25 \%$ & $50 \%$ & $75 \%$ & \\
\hline$T 3(n g / m)$ & $2.14^{\mathrm{c}}$ & $3.17^{b}$ & $3.18^{h}$ & $3.91^{\circ}$ & 0.05 \\
\hline$\Gamma 4(n g / n d)$ & $62.56^{d}$ & $113.30^{\mathrm{t}}$ & $138.50^{\circ}$ & $125^{\mathrm{h}}$ & 1.24 \\
\hline Glucose $(\mathrm{mg} / \mathrm{d} /)$ & $126.89^{: 1}$ & $107.28^{b}$ & $94.19^{c}$ & $76.93^{\mathrm{d}}$ & 1.11 \\
\hline Total proicius ( $\mathrm{gnn} / \mathrm{dl})$ & $7.18^{\mathrm{h}}$ & $8.41^{\prime \prime}$ & $7.24^{b}$ & $7.61^{\mathrm{h}}$ & 0.31 \\
\hline shbumin (gindd) & $4.77^{n}$ & $3.44^{\text {the }}$ & $3.22^{\mathrm{r}}$ & $3.85^{h}$ & 0.07 \\
\hline Cilobolin (g|m/dl) & $2.41^{\mathrm{c}}$ & $4.97^{n}$ & $4.02^{h}$ & $3.76^{\mathrm{h}}$ & 0.08 \\
\hline Triacylylyccrol (ıng/dl) & $240.83^{n}$ & $13 \% .17^{x}$ & $179.57^{\mathrm{h}}$ & $66.65^{\mathrm{d}}$ & 1.38 \\
\hline Tulal choleslerol (nıg/dl) & $22\left(1.83^{n}\right.$ & $208.10^{h}$ & $211.05^{\mathrm{h}}$ & $212.62^{b}$ & 3.15 \\
\hline IIDL (mg/dI) & $19.53^{h}$ & $38.21^{a}$ & $29.0^{\mathrm{n}}$ & $27.67^{\mathrm{a}}$ & 1.76 \\
\hline LDL (mg/d) & $152.76^{\mathrm{b}}$ & $142.92^{c}$ & $144.98^{i}$ & $161.58^{\mathrm{D}}$ & 2.12 \\
\hline \multicolumn{6}{|c|}{$\begin{array}{l}\text { 'Standard crror or lreatment means. } \\
\text { Table 8. Vitam/n } C \text { and glycogen coneentrations in hepatic lissucs and the activity of serum } \\
\text { 1ransaminascs of broiler chichens fed the cxperimental diets for } 6 \text { wecks }\end{array}$} \\
\hline \multicolumn{6}{|c|}{ Experimelltgl diels } \\
\hline \multirow[t]{2}{*}{ Parauneter } & & \multicolumn{3}{|c|}{ \% Soybean meal protcin replneemen! } & $\pm \mathrm{SE}^{\mathrm{c}}$ \\
\hline & Control & $25 \%$ & $50 \%$ & $75 \%$ & \\
\hline $\begin{array}{l}\text { Liver vilgmin } C \\
\text { (mg/loog tissue) }\end{array}$ & $46.07^{b}$ & $65.49^{4}$ & $73.37^{\prime}$ & $71.81^{\circ}$ & 2.75 \\
\hline $\begin{array}{l}\text { Liver glycogell } \\
\text { (gm/100 gm lissue) }\end{array}$ & $1.65^{\mathrm{e}}$ & $2.36^{b}$ & $2.82^{\mathrm{B}}$ & $3.06^{\circ}$ & 0.12 \\
\hline AST (U/L) & $25.02^{b}$ & $26.40^{b}$ & $23.87^{\mathrm{b}}$ & $40.32^{\mathrm{a}}$ & 1.36 \\
\hline$A L T(U / L)$ & $29.40^{\mathrm{b}}$ & $26.16^{\circ}$ & $29.35^{b}$ & $46.75^{\mathrm{B}}$ & 1.48 \\
\hline $\operatorname{GGT}(U / L)$ & $21.35^{b}$ & $19.40^{b}$ & $18.41^{\mathrm{b}}$ & $38.06^{\mathrm{B}}$ & 1.31 \\
\hline
\end{tabular}




\section{REFERENCES}

Abdel-Aal, M. S. and Attla, S. R. (1993) : Characterizalion of Black cumln (Nigella seed) sceds. Alex. Sci. Exch1., 14:483-496.

Afin, O. S. and Daghash, H. A. (1999) : Reproduclive perlomance ol Callfornla doe rabblts as affierled by feeding freshly crushed Nigella seed seeds. Alex. J. Vcl. Sv. Vul. 15, No. 5:995-1005.

Al-Apradi, F.; Fatanda, H. and Shamte, U. (1991) : The effect of plants mixturc cxiract on liver gluconeogencsis in streptozulocin induced diabctic rats. Diabct. Rcs. 18. 4:163-8.

Al-Gaby, A. M. A (1998) : Amno acid composition and biological effects ol supplementing breakl bcan and corn prolclns with Nigella sced (black cum/n) cake protcln. Nahrung 42 Nr. 5. S. 290-294.

Alexander, F. (1985) : An Introduction 60 velerinary pharmacology 4th ed. Longman. Iondon \& New York.

A. O. A. C. (1990) : Assoclation ol" Oflicial Analytical Chemists. Ollicial Melhods of Audysis.

15th cd. Washington. DC.

Aqel, M. B. (1993) : Filrect or Nigeclla seed sceds on Intcstinal smooth muscics. inter. J. I'harm. 31. : 55.

Austlc, R. E. (1994) : Diebuy threonlnc Imbalance alters threonine dehydrogrenase activity in isolated hepatic mitochondria of chicks and rals. J. Nutr. 124:1667.

Awadalla, L. M. (1997) : The use ol black sced (Nigella seed) cake in rations lor growling? shecp. Efyjutianl J. Nutrition and Fecels (spceftul Issue) 243-249.

Babayan, V. K., Koottungal, D. and Halaby, G. (1978) : Proximatc analysis. latty acid and amino acid composition of Nigella seed L. Seeds. J. lood Scl. 43: 1314-1315.

Baccari, P. J.; Jhonson, H. D. and Hahn, G. L. (1983) : Environmental heat effecl on growth. Exp. Biol. Med.173:312.

Balsom P., K. Soderlund and B. Ekblom. (1994) : Creatine In humans with speclal relerence In crcatine supplementalion. Sports Medicinc 18, 268-280.

Caroline. M. and Czarneck, I. (1991) : Influence of exogenous T4 on body welght. feed corsumption. T4 levels and myocardlal glycogsen in furazlldone- fed turkey poults. Avian (lisciascs, 35:930-936.

Caroll, N., Longley. R. and Roe, J. (1956) : Determination of glycogen in liver and muscle us- 
ins andhrone reagent .J. I3isl. Chen, 20:583-593.

Casey A. and Greenhaff P. (2000) : Does cllctary creatine supplenentalion play a role in skel-

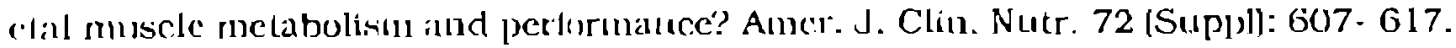

Clark, D. A.: Rozel, P. R. and Mosser, E. L. (1983) : Evaluation of a Kif lo meatsurc IIDL-C in sermm,Clin.Chem,29,1311.

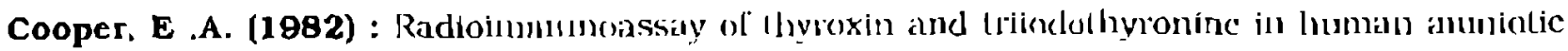
Murds. Clin. Chem. Actia 118.57-603.

Cornel, A. G., Baradwill, C. S. and David, M. M. (1949) : Colormetric detcommatum of actum Intall prolcin, Bisl. Chemis. 17: 751-768.

Doumas, B. T. (1971) : Spectrophtometric Bronocresol blue for deterninuation of albumin in sermm. Clin. Chem.Actil, 3), 87-9kj.

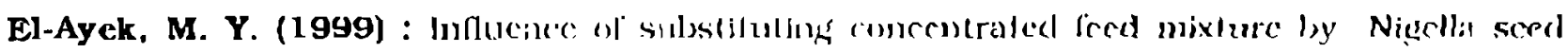
meal on : 1-Volunlary inlake. digestibilily. some rumen parametcrs and microbial pro-

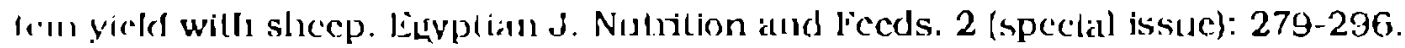

El-Dakhakhny M., Mady N. I. and Halim M. A. (2000) : Nigclla sced L. nil prolects alfainst induced hepatotoxicity and inproves scrmm lipid prolile in rats. Armeiniltellorschung 50. 0:832-6.

Farlde, M. A. and Khalld, A. G. (1987) : Studics on llac aclivily of individual platuls of all anlidlal)(ic plants mixture. Ar.ia cliabel. lat. 24:37.

Friedwald, W. T., Levy, R. I. and Fridrikeksonmen, H. (1973) : Eslmaliom of L.jol,c fil plasulia wilhoul ultracentrifugatıon. Chin. Clicm.18: 499-502.

Habeeb. A. A., Ayat. S. M. and Basuiny. S. M. (1989) : Thyroicl funclichn, sonne b)eod constitucnts and liallening performaner of rabbils as aflected by thyroxin treat-

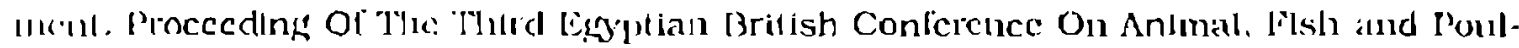
1ỵ production, Nex. Eqvist, Vol. 2, $1017-1025$.

Khalifah, M. M. (1995) : Nigella secel oil tuecal as a proletn supplenent in broiler diets. M. Se. Tliesis. Fac. Ngric., Alexandlì̃a Univ.

Khodary, R. M.. El-Azawy, M. H. and Hamdy, I. R. (1996) : Elfecd of Niffella sced on ches precluction, hatchability perecntage and some biochemiegl values in hyyng hens will reference to fertility in conckercls. The 7th Sci. Cong. 17-19 Nov. 1096. Far. Vet. Med.. Assilll. Ekypt.

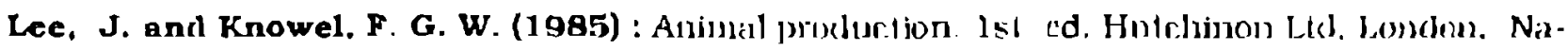




\section{T. I. Mohared \& G. R. El-Sayed}

tional Rescarch Consencil. 1994. Nutrienl Requircinents of Poultry. 9th rev. ed. Natlonal Academy Press. Wastingulou, DC.

Melattini, F. (1978) : Colorimclric determination ol scrum tolal cliolesterol. Clln. Chem. 24. $2161-2165$.

Nobukuni, K. : Koga, O. and Nishiyama, H. (1989) : The clfect of thyroid hormone on liver glyrugcn. muscle glycogen and liver lipids In chicks. JPN. J Zootech. Sci. 60: 346-350.

Persljn, J. P. and Vonderk, S. W. (1976] : Colorlmelrit: deternination of $\propto$-glutanyl transeferasce, J.Clın. Chem.Clin. Biorhenı., 14, 421.

Radwan, M. S., Aram, G. A. Bahnas M. S and Amin E. F. (2001) : Ellect of leceling Nigclia sced meal on perfonilance of local cockcrel strains. The 2nd Internatlonal Scicntific conference, 8-9 April 2001. Falc. Vel. Mcd.. Mansoura Uuiversity.

Rathee, P. S., Mishra, S. H. and Kaughal, R. (1982) : Antlinicrnblal actlvity of essentlal oil. fixed ofl and unsaponthable matter of Nigella secd linn. Indtan J. Pharmacological. Sel. $44: 8-10$.

Reitmau, S. and Frankel, S. (1957) : Colorinetric delcnulnatlon of GOT or GPT activily. An. J. Clin. Path. 28. 56.

Robert, K.: Darly, K.; peter, A and VIctor, W. (1996) : Harper blochemistry. Los syelos, Calilornli. Vol. 2, 4th Ed.. Middle East Ed.

Roe, J.: Mllls, M. B.: Oestcrline, M. and Damran, C. (1948) : Detennlnation o[ vilamln C by IJnltrophenylhydrazine uncthods. J.Biol.Chem.. 174:201.

SAS Institute, (1995) : SAS ${ }^{\circledR}$ Uscr's Guide. SAS Instltule lnc.. Cary. NC.

Schall, R. J.: Fraser, A. S.; Hansen, H. W.; Kern, C. W. and Tenso, H. J. (1978) : A sensitive mannal enzyme Immunoassay for thyroxin. Clinical Chenistry. 24: 180 1-1804.

Sharobeem, S. F. (1996) : Chemical characterkation of Nigella cake protein and its biological ellects on albino rats. Zagazig J. Agric. Res. 23. 3: 355-368.

Shetty, M.; Kuruvilla, A. K.; Ismail, B. F. and Loeb, J. N. (1998) : Stimulation of glucose transport In Clone 9 cells by insulin and thyrold homonc: role of GLUT-1 acilvation. Biochenica and Biophysica Acla. 1314:140-146.

Soltman. A. Z.: Ghazalah, A. A.; El-Samra, S. H.; Atta, A. M. and Abdo, Z. M. (1999) : The synergistle effect of either black secd or garlic wilh fat on broller perlormance and immuntty. Egyptlan J. Nutrilion and Fceds. 2 (special Issuc): 603-620. 
Taha, R, and Widnell, C. C. (1968): Ribonucleic acidl synthesis dondrug the carly acllon ol thyrould hormone. J. Arim. Sij., 25: 150.

Tennekoon, K. H., Jeevathayaparan, S., Kurukulasooriya, A. P. and Karunanayake, E. H. (1991) : Possible hepatotoxicily ol Nigclla seed seeds and Dregea volubilis lealves. J Elhmphlarmacol. ;31, 3: 283-9.

Torrance. C. J.; Devente. J. E.: Jones, J. P. and Dohm, G. L. (1997) : '7hic eflerel of thyroid hormone on GLUT-4 glucose tronspont gene statcment in rats. Endocrinolongy. 1:38:1204-1214.

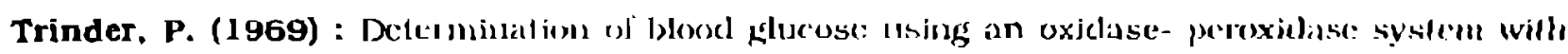
inlon carcinogende chromaken, J. Clin. l'alh. 22: 158-161.

Ustun, G.: Kent, L.; Cekin, N. and Koglu, H. (1990) : luvestlgatlon of llie Icchunolopleal properlics ol Nigclla sced l. (bluck cimin) sced (1l. JAOCS. 67: 958-960.

Whlliams, M. H.: Krelder, R. B. and Branch. J. D. (1999) : Creatine: The power Stıpplentenl Chimpaign. Llinous: Human Kinelices.

Young. D. and Postaner. L. (1975) : linæymatic and rolortmeleric: lest for delernhlnallon of Iri. ulycerides. Clin. Chem, 21: 5.

Zeoul, A.: Cherrah. Y.; Alaoul, K.; Mahassine, N.; Amarouch, H. and Hassar, Ma. (2002) : Eillects of Nigella secd fixed oil on bliond humeustasis in ral . Ethnupharmacol. J. 79. 1: $2 ; 3-26$

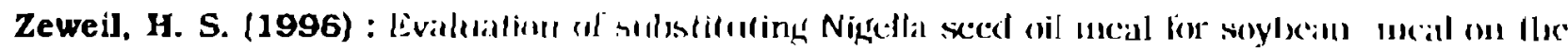
performance of growing and laving Japanesc qualls. Egypt Poult. Sci.. 11:451-177. 


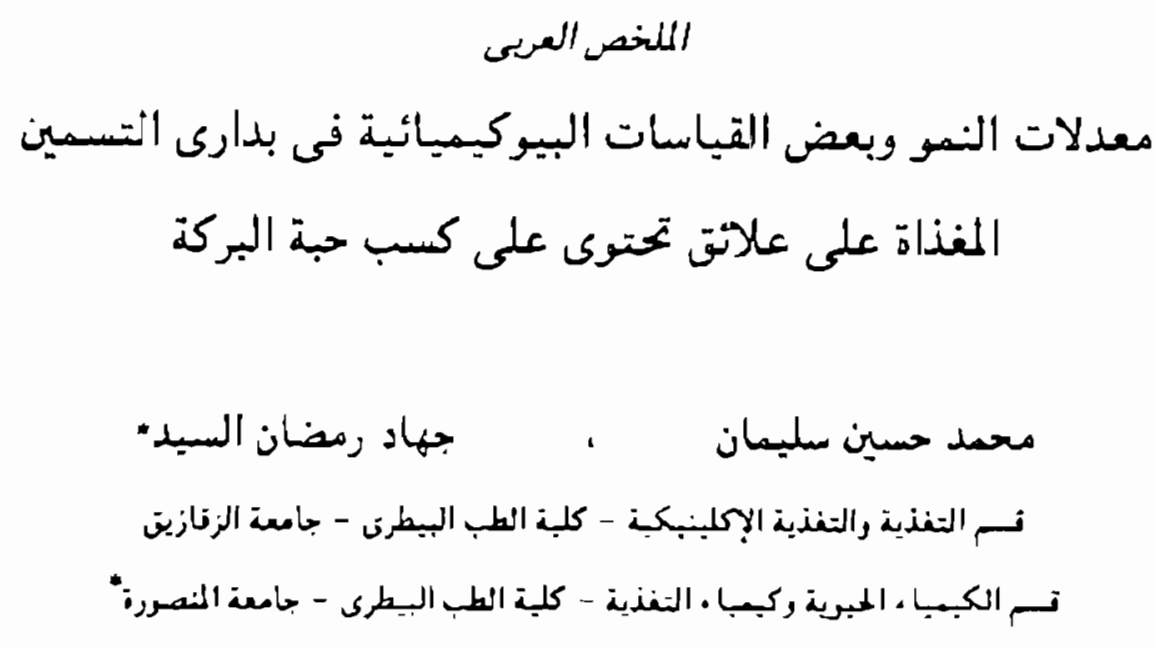

أجريت هذه الدراسة لاستبـبـان تأثير إحلال برو تين كسب حبة البركة بدلاً من بروتين كسب نرل الصويا (بز / جزء) نى علاتق بدارى التسـين على معدلات النعر وبعض القباـات البيركيميانية نى مصل الدم ونسيج الكبد، إستخدأم عدد . r مكرارات نى كل منها ، r كتكوت، ثم تكوين علايق (بادى، نامى، نامى) متسـاوية تقريباً نى محستوى البروتين

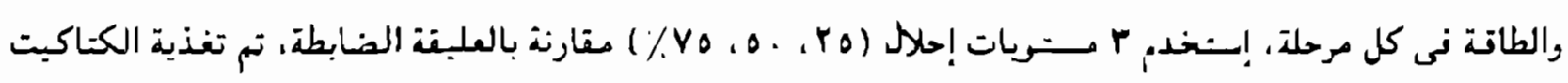

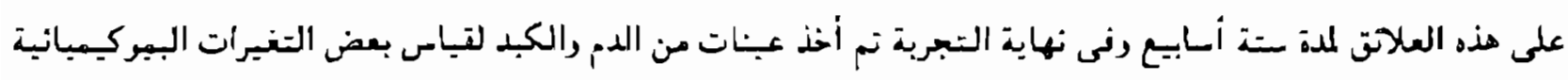
نى مصل الدم, ونسيج الكبد وكذلل نثـاط بعد إنزيات الكبد.

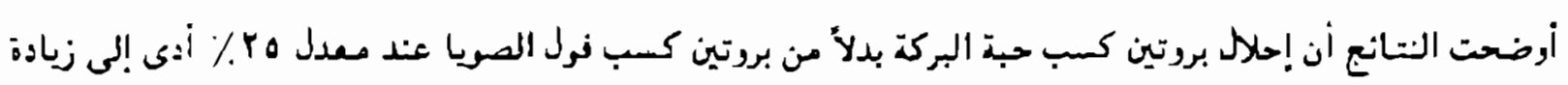

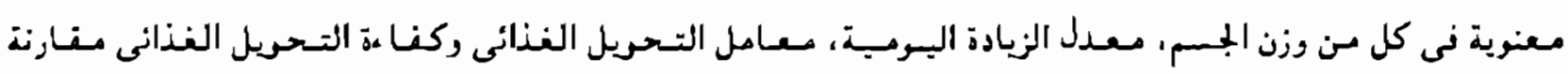
بالمعاملات الأخرى وذللك طوال نترة التجرية، بينها لم تكن هنال نروق معنرية نى هذه القياسات عند معدل إحلال . ه أر \% \% مقارنة بالعليقة الضابطة.

أدى إحلال بروتين كسب حبـة البركة جزنيا بدلا من بروتين كسب فرل الصويا إلى زيلادة معنرية نى مستوى هرمونات

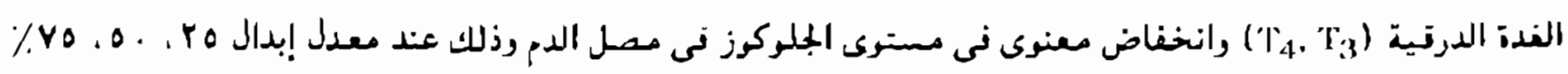

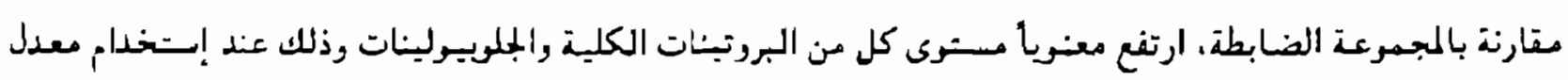

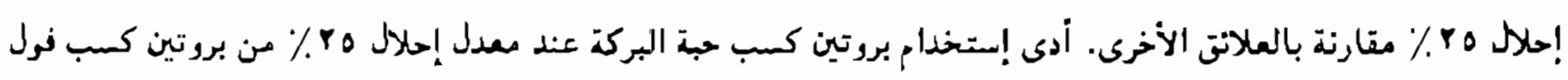




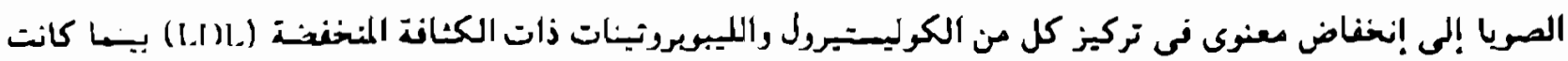

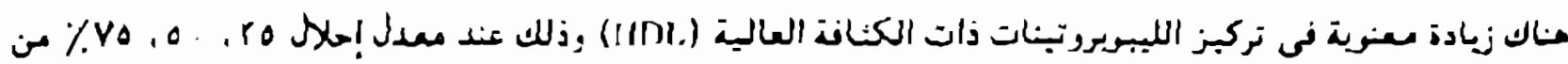
بروتين كسب فوال الصريا.

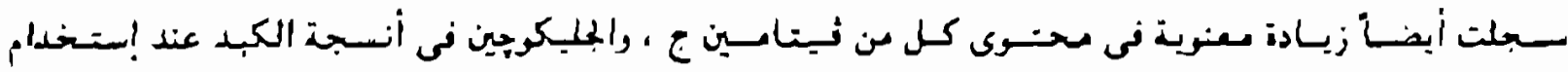

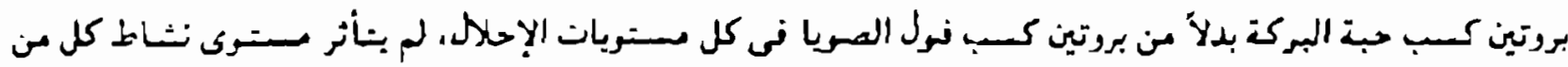

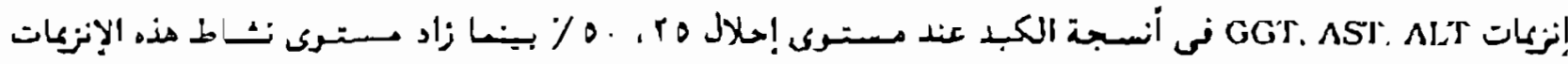

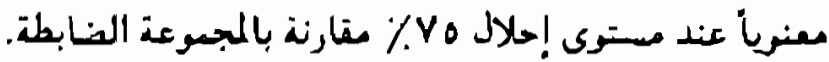

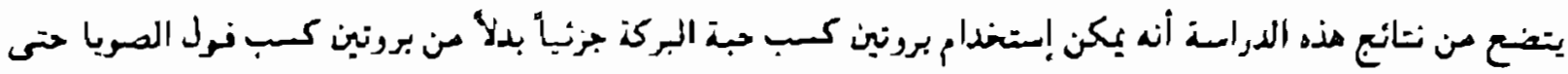

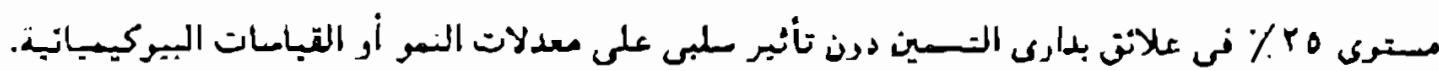

